\title{
Determinant Factors, Entrepreneurial Innovation Ability Based On Entrepreneurial Ecosystem Approach
}

\author{
Rina Uswatun Hasanah ${ }^{1}$, M. Syamsul Maarif ${ }^{2}$, Nimmi Zulbainarni $^{3}$, M. Joko Affandi ${ }^{4}$ \\ \{uswah1983@yahoo.co.id ${ }^{1}$, syamsul4958@gmail.com², nimmizu@apps.ipb.ic.id ${ }^{3}$, \\ mjokoaffandi@gmail.com ${ }^{4}$ \}
}

\begin{abstract}
Doctoral Student, IPB University, Bogor, Indonesia ${ }^{1}$, Lecturer School of Business, IPB University, Bogor, Indonesia ${ }^{2}$, Lecturer School of Business, IPB University, Bogor, Indonesia ${ }^{3}$, Lecturer School of Business, IPB University, Bogor, Indonesia ${ }^{4}$
\end{abstract}

\begin{abstract}
Entrepreneur is the essence of entrepreneurship. To succeed in today's competitive environment, entrepreneurs must become a component of the entrepreneurial ecosystem in which they jointly develop skills, innovate and thrive. The purpose of this study is to find determinant factors and strategies to improve innovation capabilities using the Fuzzy Analytical Hierarchy Process method. There are 5 experts in this research consisting of senior researchers, SMEs practitioners, government, academics and community leaders. The sample consisted of 50 business actors in North Jakarta with the types of culinary, fashion, beauty salons, accessories, seafood processing, batik, transportation, logistics and grocery traders. The results show that the highest weight is on the provision of marketing channels and is the main factor that must be considered to improve the innovation ability of business actors, next is building alliances or partnerships and the third is the use of technology.
\end{abstract}

Keywords: Entrepreneurs, Entrepreneurial Ecosystem, Fuzzy Analytical Hierarchy Process (FAHP), Innovation.

\section{Introduction}

The experience of the economic crisis in Indonesia in 1998 and the global crisis of 2008-2009 shows that one of the business fields that could survive at that time was SMEs. Small and medium enterprises did not feel the big impact at that time because they had the skills as capital to advance their business. As 
mentioned by Feld (2012) that entrepreneur is the essence of entrepreneurship[1], because entrepreneur is someone who manages the business and has the willpower to bring innovative ideas into business development. A country needs to be supported by many entrepreneurs who have attitudes and characteristics as an innovator [2]. Varis and Littunen (2010) state that innovation is "newness" regarding products, processes, production methods, and technology [3]. However, entrepreneurship cannot stand alone, as a new business that has an important contribution to economic growth, it needs support from various parties, both from the government, the business world, and other stakeholders [4].

Zahra and Nambisan (2012) define entrepreneurship as the creation of new businesses through mechanisms that involve enthusiasm (e.g. attitudes and aspirations), actors (e.g. entrepreneurs, organizations), factors (e.g. markets, regulations, financial schemes, support and culture), and processes. (eg innovation, research and development, business sophistication)[5]. If the elements of spirit, actors, factors and processes are synergized and interconnected, it will form a dynamic entrepreneurial ecosystem [6].

The entrepreneurial ecosystem is an adequate framework for studying the interdependence and relationships between various actors interacting in a complex economic system, such as individuals, organizations, entities, local, regional and national institutions, policy makers and stakeholders [7].

The problem often faced by entrepreneurs is when they are unable to achieve organizational innovativeness. The greatest difficulty is felt within themselves the entrepreneur is when they are not able to increase the innovation capability of doing business, coupled with the fact that most businesses in Indonesia are still micro (small) so that it does not allow the opening of new job opportunities. To succeed in today's competitive environment, entrepreneurs must become a component of the entrepreneurial ecosystem in which they jointly develop skills, innovate and thrive [8]. Another thing that needs to be considered is the characteristics and culture of a place, including factors that have a significant influence on the process of strengthening entrepreneurial innovation [6].

The results of the study by Hsu et al. (2007) show that small industries are often unable to achieve organizational innovativeness [9], even though innovation can be the main driver of economic growth [10]. With innovation, a business can maintain its market position and increase the efficiency of its products and services [11]. Several phenomena have been found that so far research on strengthening innovation is at the organizational level, and research at the individual level is still very limited [12]. Based on the problems previously described, the purpose of this study is to analyze the determinants 
that can increase the ability of entrepreneurial innovation based on the entrepreneurial ecosystem.

\section{Literature Review}

This research will focus on the theory of entrepreneurial ecosystem and entrepreneurial innovation capabilities.

\subsection{Entrepreneurial Ecosystem}

The World Economic Forum (2014) defines entrepreneurial ecosystem as " a system of interrelated pillars that impact the speed and ability with which entrepreneurs can create and scale new ventures in a sustainable way " or a system that has interrelated pillars that have an impact on speed and the ability of entrepreneurs to create and develop their business in a sustainable manner [13]. This includes actors who are interdependent and factors that are coordinated in such a way as to enable productive entrepreneurship in a region [6]. Isenberg (2011) details the elements in the entrepreneurial ecosystem as follows [14]:

1) Cultural Pillars which include components of social norms and the dissemination of best practices that can be role models or sources of inspiration. A culture that is conducive to entrepreneurship is supported by social norms that apply to the environment, including acceptance or tolerance of failure, risk and error, as well as a culture of innovation and creativity. In addition, the success stories that are covered by the media or social networks regarding entrepreneurship as well as a good reputation for entrepreneurship are also an element in the components of entrepreneurial culture.

2) Human Resources Pillar (HR). A skilled and trained workforce, as well as the background of parents or families who are entrepreneurial, are among the factors that shape the entrepreneurial ecosystem.

3) Education Pillar which includes education and training components. Education at various levels (elementary, middle and high) can shape the capacity and basic competencies of human resources. Technical and vocational training are also important factors in the entrepreneurial ecosystem.

4) Funding Pillars. The availability of financing in various forms according to the stage of development and the type of entrepreneurship is very important in determining the establishment and sustainability of the business being 
established. The financing needed can include credit for MSMEs, investment cooperation opportunities, venture capital, capital markets and various other forms of financing.

5) Market Pillar which includes network and consumer responsiveness. A market that is friendly in absorbing new products, shown by responsive consumers who are willing to adapt to buying new products, is needed for a dynamic entrepreneurial ecosystem. The existence of an integrated and expanding production and marketing network is also a determining factor for business sustainability.

6) Policy Pillars covering government policies and leadership. The government in its institutions which includes laws and regulations, policies and programs, budgets, and incentives can form an external carrying capacity that enables the development and strengthening of the entrepreneurial ecosystem. This government policy ideally needs to be complemented by the presence of a leader or conducive leadership shown by a leadership strategy as well as commitment and assertiveness in supporting entrepreneurship development.

7) Supporting Pillars covering components related to the role of nongovernmental organizations, professional institutions and infrastructure. The role of non-governmental organizations is needed in promoting entrepreneurship, transfer of knowledge, and strengthening networks between entrepreneurs. The role of professional institutions related to advocacy and legal assistance, accounting, banking, and associations will be very helpful, especially in the development and strengthening of entrepreneurship. Physical infrastructure support such as telecommunications, transportation and logistics, energy and water are also important factors determining a healthy and dynamic entrepreneurial ecosystem.

\subsection{Entrepreneurial Innovation Capabilities}

Innovation is a specific tool for entrepreneurs, the way they exploit change as an opportunity for a different business or service, it is capable of being presented as a discipline, capable of learning, capable of being put into practice [15]. Innovative behavior is behavior that includes exploring new opportunities and ideas, it can also include implementing new ideas, applying new knowledge and achieving increased personal or business performance. Innovative behavior is not just generating new ideas but also involves the process of implementing these ideas [16]. Rosenfeld (2002) states that innovation is the transformation 
of knowledge into new products, processes and services, the act of using something new [17]. Schermerhorn (2008) argues that innovation in a company is divided into 3 forms, namely: 1) the innovation process: producing better ways of doing things. 2) Product innovation: produce innovative products and develop services. 3) Business model: generate a method or model for companies to get money [18]

There are many ways and factors that influence small entrepreneurs to upgrade to a certain level. According to Schmitz and Knorringa (2000), to overcome the problem of stagnation in business development, it is necessary to identify the decline in income and business productivity as well as monitoring other businesses and business innovation. Every business can carry out innovation in various ways such as product innovation, improving the quality of the production process (process innovation), improving marketing performance (marketing innovation), transforming business to a higher level (functional innovation), and moving into new sectors (sectoral innovation)[19].

De Jong (2007) there are four dimensions of the innovative behavior: 1) Seeing an opportunity, an innovative process is determined chance [20]. Opportunities will trigger individuals to look for ways to improve service, delivery processes, or try to think of a new alternative regarding work processes, products or services. 2) Finding ideas, generating a concept for improvement. Finding ideas is a re-management of existing information and concepts to improve performance. Individuals who are high in this level will be able to see the solution to a problem in a different way of thinking. 3) Fighting, involving behavior to seek support and build coalitions, such as inviting and influencing employees or management, and negotiating a solution. 4) Application, individuals not only think of creative ideas on something but also apply these ideas into real action. Individual creative ideas are protected by copyright law.

So, Entrepreneurial Innovation Capability is the ability to create new things (in material or intangible form) that have significant (significant) economic value, which is generally carried out by companies or entrepreneurs as an effort to upgrade business [21].

\subsection{Fuzzy Analytical Hierarchy Process (FAHP)}

Fuzzy Analytical Hierarchy Process or FAHP is an analytical method developed from traditional AHP. In common with most humans can not make an estimate kuantitatf, unclear decision making selection inconsistencies in setting [22]. Several literatures mention the imprecision of decisions in the use of ratio comparisons [23]. Although AHP is commonly used in dealing with 
qualitative and quantitative criteria in MCDM, fuzzy AHP is considered better in describing vague decisions than traditional AHP [24]. In more complex systems, human experiences and judgments are often depicted in terms of linguistic patterns and are not clear. Therefore, a better picture can be developed into the form of quantitative data using fuzzy theory. On the other hand, the AHP method is often used in crisp applications. Traditional AHP is still not representative of human judgment. To avoid this risk, fuzzy AHP was developed to solve hierarchical fuzzy problems [24].

AHP development method which in the process uses fuzzy comparisons to analyze variables consisting of sub-variables. FAHP with the ranking method. FAHP is a combination of AHP method with fuzzy concept approach. FAHP covers the weaknesses that exist in AHP, namely problems with criteria that have more subjective characteristics. Uncertainty of numbers is represented by an order of scale. To determine the degree of membership in FAHP, a function rule in the form of a triangular fuzzy number (TFN) is used which is arranged based on a linguistic set. So the numbers on the level of importance of the AHP are transformed into the TFN scale set. TFN consists of three membership functions, namely the lowest value (l), the middle value $(\mathrm{m})$, and the highest value (n). The triangular fuzzy number (TFN) is a fuzzy set theory that helps in measurements related to human subjective judgments using language or linguistics. The essence of fuzzy AHP lies in the pairwise comparison described by the ratio scale associated with the fuzzy scale [25].

Among the commonly used membership functions, triangular and trapezopidal are the most frequently used functions because of their simplicity in modeling and easy interpretation [26]. The set of TFN numbers in this study is as shown in Table 1.

Table 1. Comparison scale of fuzzy importance and TFN numbers

\begin{tabular}{|c|c|c|c|}
\hline $\begin{array}{c}\text { Level } \\
\text { Interest }\end{array}$ & Number Fuzzy & Definition & $\begin{array}{c}\text { Membership } \\
\text { Function }\end{array}$ \\
\hline 1 & \multicolumn{1}{c|}{ Just as Important } & $(1,1,2)$ \\
\hline 3 & $\sqrt{5}$ & A little bit more important & $(2,3,4)$ \\
\hline 5 & $\sqrt{7}$ & More Important & $(4,5,6)$ \\
\hline 7 & $\sqrt{9}$ & Absolutes are more important & $(8,9,10)$ \\
\hline 9 & & Very Important & $(6,7,8)$ \\
\hline
\end{tabular}


And the membership functions for pairwise comparisons are made using the ratio scale detailed as in Figure 1.

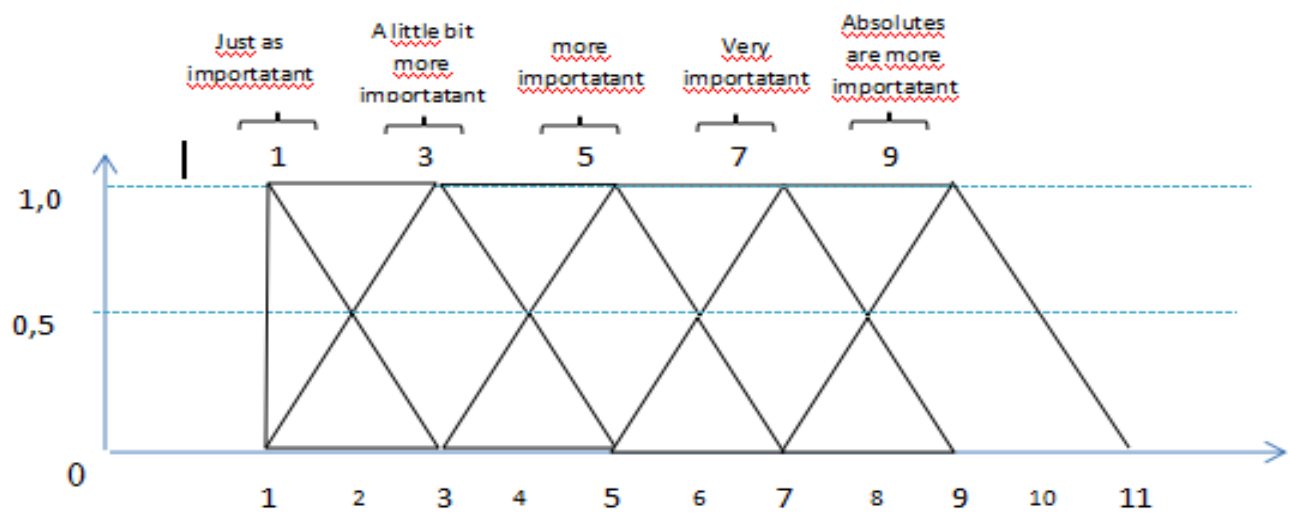

Figure. 1. Membership Function of Triangular Fuzzy Numbers

AHP fuzzy method is used for the selection of an alternative and problem adjustment by combining the concept of fuzzy theory and analysis of hierarchical structures. The use of fuzzy methods allows decision makers to enter qualitative and quantitative data into the decision model. For this reason, decision makers usually feel more confident about giving an assessment in the form of a range than an assessment in the form of a particular value [26].

\section{Research Methodology}

This study examines in depth the factors of increasing the ability of entrepreneurial innovation based on the entrepreneurial ecosystem through the expert system decision-making method using Fuzzy Analytical Hierarchy Process (FAHP) software so that the best strategy can be determined as an effort to strengthen entrepreneurial innovation. This research begins with a situational analysis using analysis of external factors (e.g. culture, policy) and internal factors (e.g. education, motivation), followed by interviews and Focus Group Discussions (FGD) with business actors in Koja, Cilincing, and Tanjung Priok Districts.

\subsection{Research Sample}

The number of business actors sampled is 50 people with different types of business, including culinary, fashion, seafood processing and home 
industry. Sampling was obtained on the recommendation of the North Jakarta regional government.

\subsection{Hierarchical Structure}

The next stage is the hierarchical arrangement. In this study, the hierarchy arrangement was obtained from the opinions of experts, theories, and government policies. So, in determining the right and ideal composition, the researcher conducted the Individual Depth Interview (IDI) technique with five experts consisting of senior researchers, SMEs practitioners, government, academics, and community leaders. The theory used is from Isenberg (2011) which states that in the pillars of the entrepreneurial ecosystem there are factors that can affect the increase in entrepreneurial innovation capabilities. So the hierarchical structure is as follows see Figure 2 :

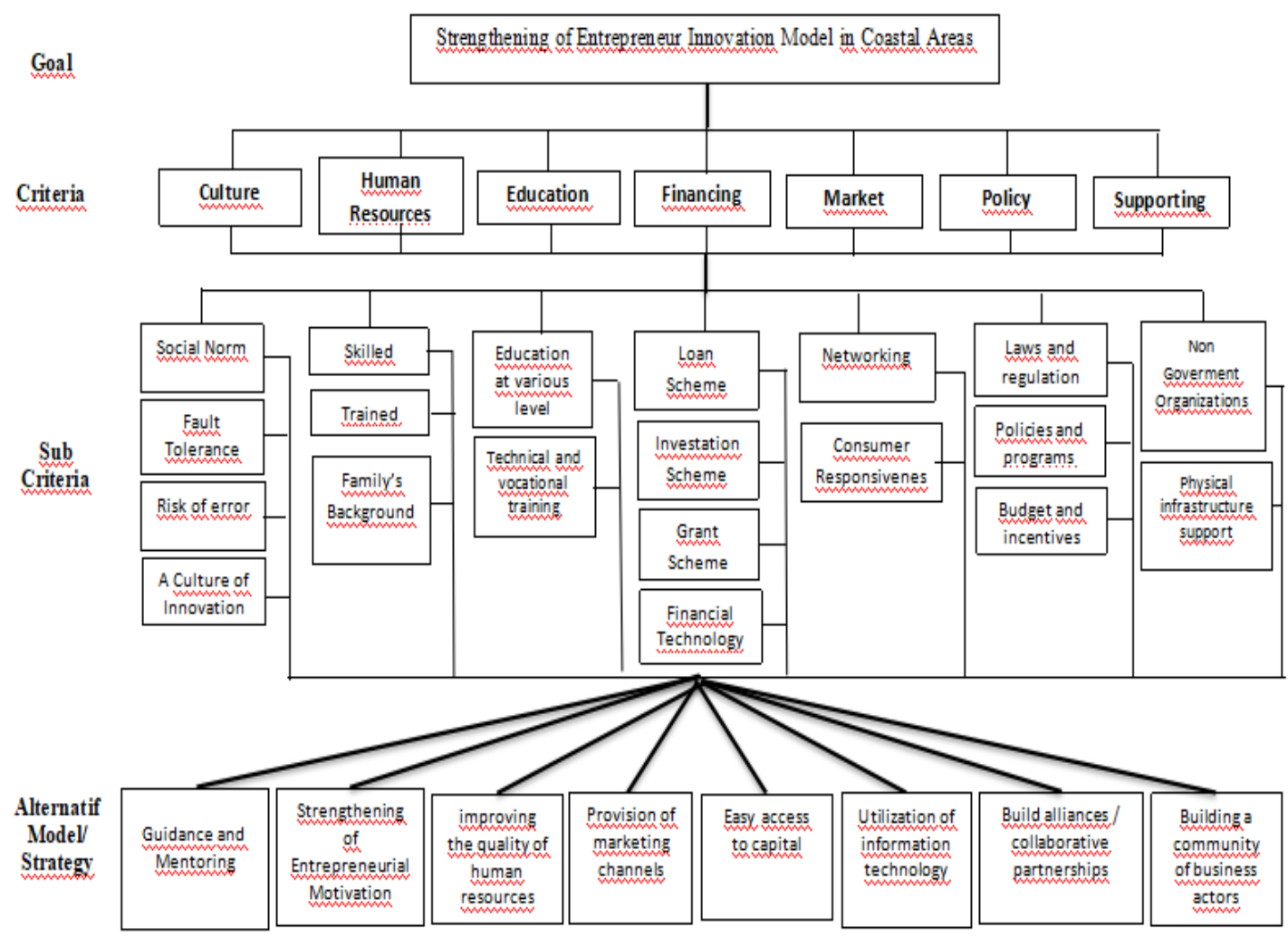

Figure 2. Hierarchical Structure Chart 


\section{Results and Discussion}

Based on the Law of the Republic of Indonesia Number 11 of 2019 concerning the National System of Science and Technology, it is stated that the definition of innovation is the result of thought, research, development, assessment and or application that contains elements of novelty and has been applied and provides economic and / or social benefits. Article 34 paragraph 1 of this Law states that what is meant by developing innovation is to facilitate the use, adoption, incubation, partnership, strengthening of areas of science and technology in accordance with regional readiness and excellence, promotion and use of innovation results in sustainable development programs, including distribution roles with Business Entities.

To encourage the readiness of innovation to enter the commercialization stage and reduce the risk of failure in the use of innovative products, it is necessary to measure and determine the level of innovation readiness. The Innovation Readiness Level or known as Katsinov is a method for estimating the innovation readiness of an innovation program in companies, Research and Development Institutions, and universities in terms of technology, market, organization, partnership, risk, manufacturing, and investment. The results of measurement and determination of Katsinov which are integrated into the innovation product database are important information for efforts to strengthen innovation to achieve the commercialization of sustainable innovation products.

The basic problems that are often faced by small business owners are weak market penetration and the insufficient coverage of the marketing area. Therefore, to advance small businesses that have strong competitiveness is to build a good marketing strategy and right on target. Marketing is an effort to arrange strategies and ways so that consumers want to spend the money they have to use products or services owned by a company, in this case small and medium enterprises. With a good marketing strategy the position of small and medium enterprises is strong and should be taken into account in national economic activities which ultimately bring benefits to these businesses[27].

Based on the marketing problems experienced by SMEs in Indonesia. There are several ways that can be done to improve and enhance the right marketing strategy for SMEs in Indonesia. Marketing strategies as Kotler (2005) states include: Perform STP (Segmenting, Targeting, and Positioning), improve product quality, distribution strategy, pricing strategy, promotion strategy, use of information technology, seeking competitive advantage [28]. Based on analysis and evaluation by the 2016 National Planning Agency on entrepreneurship development that has been carried out in Indonesia, it shows a holistic model of entrepreneurship development that should be carried out in 
Indonesia to create new entrepreneurs in a more coordinated manner through the Market System model approach.

Strategy analysis using the FAHP method is carried out to determine the results of factor analysis based on the perspective of interest, this is done to show the dominant factors that can increase the ability of entrepreneurial innovation. In completing the FAHP analysis stages in this study, researchers used Fuzzy AHP software as shown in Figure 3.

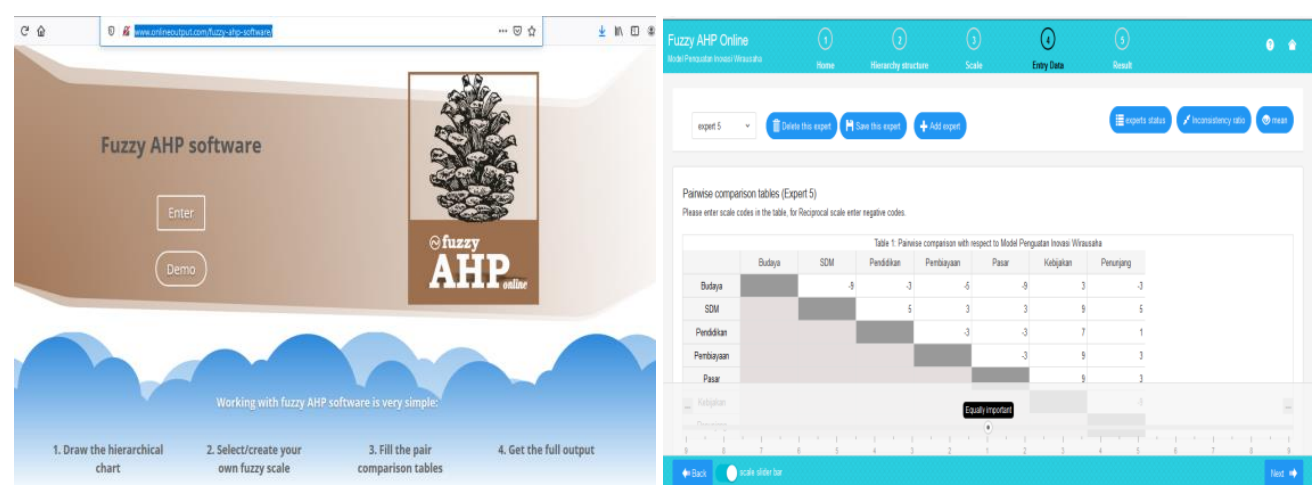

Figure 3. AHP Fuzzy Software Display

Based on the results of the analysis of Fuzzy Analytical Hierarchy Process (FAHP) using FAHP software, the weight values of each part of the structure are obtained with the following explanation :

\subsection{Results of Weighted Criteria and Sub Criteria}

The main criterion that can support these strategies is education $(0.145)$, where education can encourage the improvement of the quality of human resources. This quality improvement will trigger changes in thought patterns, behavior, habits so that people are sensitive to changes in innovation. In essence, education can make people aware of information, and innovation is formed on several factors that will later have an impact on the evolution and change slowly but can be done because of habits that have become a culture in the communities of Koja, Cilincing and Tanjung Priok Districts. The main sub-criteria priority for the education criteria are technical and vocational training (0.516), 
Then the second criterion is HR (0.144) with the main sub-criteria priority on the HR criteria, namely Skilled (0.379). Of course, skilled human resources can help people understand technology as a form of entrepreneurial innovation renewal. To be innovative, one must quickly adapt to the development of technological advances that fill many sectors of life today and in the future. These innovations can be strengthened and developed by skilled human resources.

The third criterion is Culture (0.143) and Markets (0.143), the main subcriteria priority on the Cultural criteria is the Culture of Innovation (0.28), meaning that one of the important elements and is the spirit for the development and success of strengthening the innovation system is the culture of innovation. This element aims to build and develop innovation-based entrepreneurship and build innovative creativity in North Jakarta. The main sub-criteria priority in the Market criteria is Networking (0.541), where the market criteria of course the priority that must be supported is networking because networking plays a very vital role and can affect businesses on a large scale. Solid networking can make a business stronger and support new business opportunities on the recommendation of business partners.

While the fourth criterion is Financing (0.142) and Policy (0.142), the main sub-criteria priority in the Financing criterion is the Loan Scheme (0.254), where the financing of the loan scheme focuses on efforts to find alternative sources of financing that are not dependent. With the loan scheme, it can expand people's business access in North Jakarta to be able to innovate. The main subcriteria priority on the Policy criteria is Budget and Incentives (0.55), wherein the development of innovation, budget, and incentives are needed. Weak policies related to budgets and incentives have an impact on strengthening innovation that has stopped at the research level and findings at the academic level. If budget policies and incentives can be implemented, at least allocate a budget of at least one percent of GDP then,

The last criterion is Support (0.141) with the main sub-criteria priority on the Supporting criteria, namely Infrastructure Support (0.516), wherein supporting the strengthening of innovation for coastal communities, adequate infrastructure support is needed, this is aimed at smoothing the distribution of technology and expanding marketing. The limited infrastructure owned by the people of North Jakarta directly affects the development of the economy and services between regions.

\subsection{Alternative Strategies}


The alternative strategies to be implemented in strengthening entrepreneurial innovation are formulated into five strata. The strategic alternative that is considered the most reliable and has become a top priority is the provision of marketing channels (0.134), where the availability of effective marketing channels aims to seize market share which will affect entrepreneurial sustainability. Corporate channels are critical issues facing management. Marketing channels can also turn potential buyers into profitable orders because marketing channels not only serve the market but they also shape the market.

Sawitri and Andarwati (2014) state that one of the factors that can affect the performance of entrepreneurial ventures is the ability to develop creative marketing programs [29]. Creative marketing programs can be interpreted as the development of the implementation or implementation of strategies carried out in the market (form of change), which shows a significant difference from marketing practices. Entrepreneurial activities in managing their business without the ability to create creative marketing programs will be difficult to develop because they only have a vision but are not accompanied by a strategy that supports it. Morris and Lewis (1995) also explain the importance of the existence of a marketing program that supports the success of business management by young entrepreneurs [30]. Likewise, research conducted by Hadiyati (2012) also revealed that creativity in marketing programs is needed to support business management [31].

The next strategic alternatives is Build alliances / partnership (0132), where both strategies are necessary to expand the market and business network in order to enhance the success of the coastal areas are often involved de $\mathrm{n}$ gan market access difficulties. Strategic alliances encourage business actors to make better innovations and lead to good cooperation as well. Marketing channels and market alliances if done can include markets, technology, capital and human resources. The alliance strategy enables coastal area entrepreneurs to increase their business competitive advantage through access to partner or partner resources. These results support the statement put forward by $\mathrm{Li}$ and Chen (1999) where building a strategic alliance is an important aspect because it is a major dimension needed to increase the effectiveness of a company [32]. The existence of a partnership between business managers will provide advantages in terms of certainty of marketing results and relatively more stable profits, providing easy access to capital, obtaining quality seeds as well as guidance on cultivation techniques and post-harvest handling, and lower risk of loss [33].

Then the third alternative is the Utilization of Information Technology (0.13), where in increasing entrepreneurial innovation, of course, the role of technology is very important, especially in terms of marketing, with the right use of information technology, of course, the innovation applied will be stronger 
and more effective. These results are in line with the research of Gemiharto and Sugiana (2016) where in their research it was found that the use of information technology in the development of innovation has a significant role in encouraging an increase in the innovative capacity of entrepreneurs [34]. In addition, by increasing awareness of the entrepreneurial needs of coastal communities in the use of information technology, it can increase business turnover. According to Nikoloski (2014), the importance of information technology for the business world can be useful as a management tool to optimize information processing to improve business. Regardless of the size of the company, technology has tangible and intangible benefits that will generate profits and products that satisfy consumers [35]. Technological infrastructure can impact culture, efficiency and business relationships. The strategic role of information systems that involves the use of information technology to develop products, services and capabilities can provide strategic advantages in competition in the global market. Information technology supports a company's competitive and strategic position [35]. Nikoloski (2014) also states that information technology can be used to implement various competitive strategies, namely five basic competitive strategies (differentiation, cost, innovation, growth, alliances) and other ways that companies can use information systems strategically.

The fourth alternative strategy is the Ease of Access to Capital (0.127), where as it is known that access to capital institutions in coastal areas is quite difficult, this also results in limited entrepreneurial innovation that can be carried out due to limited loan capital. With this strategy, fishermen or coastal entrepreneurs can more easily borrow capital to increase and strengthen their business innovation. These results support the statement of Sari et.al (2015) where the limited ability of banks to channel credit needs to be supported by opening access to capital markets for entrepreneurs and removing obstacles to the development of non-bank financial institutions, such as venture capital and crowdfunding [36].

The fifth alternative strategy is to Improve the Quality of Human Resources (0.124), meaning that human resources must be able to understand the innovations that will be implemented. According to Fatkhurahman (2018), the main problem for businesses in the region today is related to difficulties in facing superior competition, this is closely related to limited human resources as business managers who are able to realize their advantages in doing business [37]. According to Nurseto (2004), the effort to create strong new entrepreneurs will be better if it is carried out on university graduates who already have a high scientific and intellectual basis [38]. This is because competition in the era of globalization demands the ability of a quality entrepreneur. One of the patterns 
of developing a strong and superior entrepreneur is by providing training and internships supported by facilities / access to technology, management, markets, capital and information through business incubation.

The sixth alternative is to Build a Community of Business Actors (0.123). This strategy aims to strengthen relationships by building communities so that information dissemination is more effective because it is carried out jointly, besides the purpose of building a community of business actors in coastal areas is to form a coalition network. and communication between business people and local organizations. This result is supported by Diana (2019) research on several MSEs in West Sumatra. The results show that MSEs that are members of cooperatives (communities) are three times more likely to get access to capital from formal financial institutions than businesses that are not cooperative members [39].

The seventh alternative, namely, Guidance and mentoring (0.118) and Strengthening Entrepreneurial Motivation (0.118), meaning that fulfilling the strengthening of innovation and entrepreneurship requires guidance related to entrepreneurship that is appropriate to be carried out in coastal areas, after guidance, of course the people in North Jakarta cannot directly just being released is also needed guidance because strengthening innovation can work properly, besides that it requires encouragement or strength within the individual to maintain his entrepreneurial spirit, especially related to strengthening innovation, entrepreneurs in coastal areas must further increase motivation so that it can affect business performance better. These results are in line with research conducted by Thesman and Ardianti (2014) where entrepreneurial motivation has a significant relationship with business performance, so that individuals who are highly motivated in running their business will achieve maximum performance in doing business [40].

The ranking of priority factors can be seen in table 2 .

Table 2 Alternative strategies for increasing the ability of entrepreneurial innovation

\begin{tabular}{lcrc}
\hline No. & Alternative Strategies & Priority Vector & Priority \\
\hline 1. & Provision of Marketing Channels & $\mathbf{0 . 1 3 4}$ & $\mathbf{1}$
\end{tabular}




\begin{tabular}{llrl} 
2. & Building Alliance / Cooperation & $\mathbf{0 . 1 3 2}$ & $\mathbf{2}$ \\
& $\begin{array}{l}\text { Partnerships } \\
\text { Utilization of Information }\end{array}$ & $\mathbf{0 . 1 3}$ & $\mathbf{3}$ \\
3. & $\begin{array}{l}\text { Technology } \\
\text { Ease of Access to Capital }\end{array}$ & $\mathbf{0 . 1 2 7}$ & $\mathbf{4}$ \\
5. $\quad \begin{array}{l}\text { Improving the quality of human } \\
\text { resources }\end{array}$ & $\mathbf{0 . 1 2 4}$ & $\mathbf{5}$ \\
6. $\quad \begin{array}{l}\text { Building a Community of Business } \\
\text { Actors }\end{array}$ & $\mathbf{0 . 1 2 3}$ & $\mathbf{6}$ \\
7. & $\begin{array}{l}\mathbf{0 . 1 1 8} \\
\text { Sentoring }\end{array}$ & $\mathbf{7}$ \\
\hline
\end{tabular}

\section{Conclusion}

A lot of research is done to identify the pillars in the entrepreneurial ecosystem. Most of the results show that government policies on entrepreneurship, financial support, friendly and accessible markets, education and training, and cultural support greatly affect entrepreneurial performance. This research showed that the main factor of strengthen entrepreneurial innovation is the provision of marketing channels $(0.134)$, where the availability of effective marketing channels is able to grab market share which will affect the sustainability of the entrepreneurship. Marketing channels can also turn potential buyers into profitable orders because the marketing channels not only serve the market but also shape the market. Good marketing channels will increase the willingness of business actors to create innovative ideas in terms of both products and services.

There are two implications in this research, policy and business implications. From a policy perspective, this research will have an impact on the material for consideration and formulation of program policies for strengthening entrepreneurial innovation. As for the business implications, it is hoped that this model can add to the literature in the field of entrepreneurship with the existence of the marketing channel factor as a strategy to strengthen entrepreneurial innovation.

The limitations of this study are the number of samples and the research area, so for further research it can be added to the number of samples and a wider area of coverage. The next suggestion for further research is to discuss a 
marketing strategy strengthening model for increasing entrepreneurial innovation.

\section{References}

[1] Feld B. Startup Communities; Building an Entrepreneurial Ecosystem in Your City. New York; Wiley. 2012.

[2] Schumpeter JA. The Theory of Economic Development. An Inquiry into Profits, Capital, Credit, Interest and the Business Cycle. Harvard University. 1934.

[3] Varis M, Littunen H. 2010. Types of innovation, sources of information and performance in entrepreneurial SMEs. European. Journal of Innovation Management, 13 (2), 128-154.

[4] Wennekers S, Thurik R. Linking Entrepreneurship and Economic Growth. Small Business Economics 13: 27-55. Kluwer Academic Publishers. Printed in the Netherlands. 1999.

[5] Zahra SA., Nambisan S. Entrepreneurship and Strategic Thinking in Business Ecosystems. Business Horizons, 55 (3), 2012, 219-229.

[6] Stam E., Spigel B. Entrepreneurial Ecosystems. Utrecht School of Economics. Tjalling C. Koopmans Research Institute. Discussion Paper Series, 2016, 16-13.

[7] Purbasari R., Wijaya C., Rahayu N. The Entrepreneurial Ecosystems as A Network-Rich Systems: A Systematic Mapping Study. Academy of Entrepreneurship Journal, Vol 25, 2019. Issue 2.

[8] Purbasari R, Muhyi HA, Sukoco I. Actors and Their Roles in Entrepreneurial Ecosystem: A Network Theory Perspective: Cooperative Study in Sukabumi, West Java. Review of Integrative Business and Economics Research, Vol. 9, Supplementary Issue 3, 2020 pg 240-253.

[9] Hsu CI, Carol MN, Lawler JJ. Toward a Model of Organizational Human Capital Development: Preliminary Evidence from Taiwan. Asia Pacific Business Review Vol. 13, No. 2, 251-275, April 2007.

[10] Evangelista R. Lucchese M, Meliciani V. Business services, innovation and sectoral growth. Structural Change and Economic Dynamics Volume 25, June 2013, Pg 119-132. Elsevier. 2013.

[11] Ettlie JE, Rosenthal SR. Service versus Manufacturing Innovation. Journal of Product Innovation Management, 28, 285-299. 2011.

[12] Amo BW., Kolvereid L. Organizational Strategy, Individual Personality and Innovation Behavior. Journal of Entreprising Culture, 13(1), 7-20. 2005.

[13] World Economic Forum. Entrepreneurial Ecosystems Around the Globe and Early Stage Company Growth Dynamics. 2014. (https://www.weforum.org/reports/entrepreneurialecosystemsaround-globe-and-company-growth-dynamics).

[14] Isenberg, D. The entrepreneurship ecosystem strategy as a new paradigm for economic policy: Principles for cultivating entrepreneurship. Dublin, Ireland: Institute of International European Affairs. 2011.

[15] Drucker, Peter F.Innovation and Entrepreneurship Practice and Principles, New York, Harper \& Row, Publisher, Inc. 1985 
[16] De Jong J, Hartog DD. Measuring Innovative Work Behavior. Article in Creativity and Innovation Management. Vol. 19 (1) 2010, pg 23-36.

[17] Rosenfeld SA. Creating Smart Systems. A Guide to Cluster Strategies in Less Favored Regions.www.rtsinc.org. 2002.

[18] Schermerhorn JR. Management; Twelfth Edition Learn Succeed.John Wiley and Sons, Inc. USA. 2008.

[19] Schmitz H, Knorringa P.Learning from Global Buyers. Journal of Development Studies. Vol. 37. No. 2. 2000, pp. $177-205$.

[20] De Jong J. Individual innovation: the connection between leadership and employee's innovative work behavior. Dissertation Faculty of Economics and Business. University of Amsterdam. 2007.

[21] Edquist, C.Innovation Policy in the Systems of Innovation Approach: some Basic Principles. In Fischer MM and J. Fröhllich (eds.) Knowledge, Complexity and Innovation Systems, Berlin: Springer Verlag. 2001.

[22] Elveny M, Rahmadsyah. Analysis of the Fuzzy Analytic Hierarchy Process (FAHP) Method in Determining the Position. TECHSI Vol 4 (1) 2014 pg 111-126: Journal of Informatics Engineering Research.

[23] Faisol A, Muslim MA, Suyono H. Comparison of Fuzzy AHP with AHP in Property Investment Decision Support Systems. EECCIS Journal Vol. 8 (2) 2014 pg 123-128.

[24] Chang DY. Applications of The Extent Analysis Method on Fuzzy AHP. European Journal of Operational Research, 1996, 649-655.

[25] Shega HNH, Rahmawati R, Yasin H. Determination of student priority factors in choosing blackberry brand cell phones with fuzzy AHP. Gaussian Journal, Vol 1 (1) 2012, 73-82.

[26] Marimin, Djatna T, Suharjito, Hidayat S, Utama DN, Astuti R, Martini S. Techniques and Analysis of Fuzzy Decision Making in Supply Chain Management. IPB Press. Taman Kencana Bogor, Indonesia. 2013.

[27] Wibowo DH, Arifin Z, Sunarti. 2015. Analysis of Marketing Strategies to Increase the Competitiveness of MSMEs (Study on Batik Diajeng Solo). Jurnal Administratsi Bisnis (JAB), Vol 29 No 1 hal 59-66. 2015.

[28] Kotler P. Marketing Management. Jakarta: Indeks Media Group. 2005.

[29] Savitri D, Andarwati, Ipolito S . The Influence of Entrepreneurial Orientation, Marketing Program Creativity and Environmental Dynamics to Marketing Performance (Studies on the Tais Industry in Dili, Timor Leste), Indonesian Management Forum Vol. 6 Medan , 2014 .

[30] Hadiyati E. Creativity and Innovation Effect on Entrepreneurship Marketing in Small Business. Journal of Innovation and Entrepreneurship, Vol 1.pg. 135-151. 2012.

[31] Morris MH, Lewis P S. Determinants of Entrepreneurial Activity, Implications for Marketing, European Journal of Marketing, Vol. 29 No. 7, 1995, pg . 31-48 .

[32] Li M and Chen R. Strategic Alliances and New Product Development: An Empirical Study of The US Semiconductor Start-Up Firms. Advance in Competitiveness Research. 1999, $\operatorname{pg} 7-35$.

[33] Saparuddin M., Bado, B. The Effect of Business Partnerships on Business Performance in Small and Medium Enterprises (UKM) and Cooperatives in Jeneponto Regency, South Sulawesi. Econoscience, 9 (2), 2011 pg 161-191.

[34] Gemiharto I and Sugiana D. Utilization of Information Technology in Building Innovation Capacity and Regional Competitiveness. Proceedings of the National Communication Seminar. 2016 pg 247-256. 
[35] Nikoloski K. The Role of Information Technology in the Business Sector. International Journal of Science and Research (IJSR). Vol 3 issue 12, 2014 pg 303-309, ISSN 23197064.

[36] Sari YR, Manullang N, Narjoko D, Anas T, Purwanti W, Khulasoh L, Paramitha F. Mapping and Strategies for Increasing SMEs Competitiveness in Facing MEA 2015 and Post MEA 2025. Bank Indonesia Working Paper. 2015. 1-95.

[37] Fatkhurahman. The Influence of the Spirit of Entrepreneurship and Partnership on Business Policy and Management Performance and Its Impact on the Competitive Advantage of the Small Food Industry in Riau Province. Thesis (S3) dissertation, Pasundan University. 2018.

[38] Nurseto T. Strategies to grow Resilient Small and Medium Enterprise. Journal of Economics \& Education. Vol. 1 (1) 2004: 96-105.

[39] Diana R. Analysis Of Capital Accessibility Of Small Micro Enterprises To Formal Financial Institutions In West Sumatra Province. Journal of Economics and Development Vol 27 ( 1 ) 2019 pg 67-80.

[40] Thesman $\mathrm{T}$ and Ardianti R. The Relationship of Entrepreneurial Motivation to the Performance of Micro and Small Business Enterprises in Food and Beverage Sector in Surabaya and Sidoarjo. AGORA Vol. 2. 2014. 